\title{
ПАСИВНО-АКТИВНИЙ МЕТОД АДАПТИВНОЇ ЛОКАЦІї
}

\begin{abstract}
Анотація: Розглядається фізична суть та дається математичне обґрунтування процесу отримання радіолокаційної інформації, що виникає при опромінюванні композитного радіопоглинаючого матеріалу надвисокочастотним електромагнітним коливанням. Аналіз існуючих способів вторинної обробки радіолокаційної інформації свідчить про неможливість їх застосування при супроводженні в умовах виникнення інформаційної невизначеності про параметри руху. Тому виникає необхідність розробки інших методів і алгоритмів для вирішення завдання надійного супроводження.

Ключові слова: радіолокаційна інформація, композитне покриття, резонанс, сигнал.
\end{abstract}

\section{Вступ}

Зменшення радіолокаційної помітності є одним з напрямків розвитку сучасних літаків на основі використання властивостей композиційних матеріалів, якими вкритий фюзеляж даного типу та спеціальних геометричних форм щодо поглинання та розсіювання електромагнітних випромінювань. Це підвищує надійність планера, але погіршуе безпеку польотів.

Проведені розрахунки вказують на недостатню ефективність радіотехнічних систем (РТC) у виявлені літаків зі штучно зменшеною ефективною площею віддзеркалення (EПВ) [1]. Зважаючи на те, що питома вага сучасних малопомітних літаків постійно зростає, стає необхідним удосконалення основних систем РТС.

Метою статті є математичний опис фрізичної моделі взаємодії електромагнітного поля НВЧ з кристалічною структурою радіопоглинаючих діелектриків. Для визначення можливих напрямків вирішення проблеми підвищення ефективності РТС необхідно в першу чергу піддати детальному аналізу фізичні процеси, які покладені в основу штучного зменшення ЕПВ, обгрунтувати можливості та розробити наукові методи удосконалення основних систем РТС щодо виявлення літальних апаратів, розроблених з використанням технології штучного зменшення ЕПВ.

Стаття присвячується аналізу напрямів та методів можливого розв'язання завдання виявлення та визначення параметрів руху літаків зі штучно зменшеною ЕПВ.

\section{Основна частина}

Ефективне отримання інформації про літаки зі штучно зменшеною ЕПВ в першу чергу залежить від вирішення задачі виявлення таких об'єктів. У загальному випадку при виявленні літаків зі зменшеною ЕПВ радіолокаційна станція отримуе віддзеркалений

(c) I.P. Пархомей, О.Ю. Кагаров, 2015 
сигнал, потужності якого недостатньо для перевищення порогового значення прийняття рішення про їх виявлення. Це відбувається внаслідок поглинання електромагнітних хвиль опромінювання в шарах радіопоглинаючого матеріалу, яким вкрита поверхня літальних апаратів зазначеного типу, а також завдяки іншим заходам щодо зменшення радіолокаційної помітності.

Ефект зменшення ЕПВ сучасних малопомітних літаків досягається в основному за рахунок використання покриттів, головною властивістю яких є поглинання або розсіювання електромагнітних хвиль. Цей ефект досягається різними шляхами, а саме, використанням інтерференційних властивостей покриття з певним малюнком поверхні та використанням композиційних матеріалів в декілька шарів з різними коефіцієнтами переломлення.

Для детального дослідження зазначеного ефекту з метою вивчення процесу поглинання електромагнітного випромінювання та пошуку можливих шляхів подолання його шкідливих наслідків був проведений експеримент за допомогою установки, яка складається з передавача електромагнітного випромінювання, приймача та прямокутного хвилеводу. В хвилеводі розміщався зразок радіопоглинаючого матеріалу, що може змінювати кут опромінювання (кут падіння електромагнітного сигналу на поверхню матеріалу) зондуючим сигналом. Вихідні дані для експерименту: товщина шару радіопоглинаючого матеріалу - 1,67 мм, імпульсна потужність - 1 Вт, тривалість імпульсу - 0,5 мкс, період між імпульсами - 700 мкс, кути опромінювання - 180 град,

Об'єм простору, в якому здійснювалося дослідження зразків радіопоглинаючого матеріалу, обмежувався розмірами хвилеводу, вимірювання проводилися при кімнатній температурі без впливу зовнішніх штучних енергетичних полів.

В експерименті проводилось вимірювання параметрів радіопоглинаючого матеріалу за допомогою методу короткохвильового замикання (вимірювання електричної і магнітної проникностей радіопоглинаючого матеріалу в прямокутному хвилеводі) і були отримані графіки [1] розподілу енергії віддзеркаленого сигналу в залежності від кута опромінювання при однопозиційній локації.

Зразок радіопоглинаючого матеріалу був встановлений всередині хвилеводу й опромінювався прямокутними радіоімпульсами високої частоти для оцінки його властивостей щодо розсіювання електромагнітних хвиль. В кожному досліді відповідним чином змінювали ракурс опромінювання зразка за допомогою мікрометричного гвинта від 0 до 180 градусів. В ході проведення експерименту змінювалися частоти опромінювання з встановлюванням зразку матеріалу у відповідний хвилевод. Після проведення вимірювань таким самим чином був досліджений другий зразок рідіопоглинаючого матеріалу. 
В ході проведеного експерименту було визначено, що поглинання електромагнітної енергії дослідженим радіопоглинаючим матеріалом носить нерівномірний характер і залежить від кута опромінювання поверхні матеріалу зразка.

Основним результатом проведеного дослідження було отримання ефекту збудження та перевипромінювання при зміні стану прикордонного шару радіопоглинаючого матеріалу при його опроміненні високочастотним радіолокаційним сигналом на певних частотах [2].

Цей ефект можна пояснити наступним чином: якщо зважити на те, що кристалічна структура радіопоглинаючого матеріалу може бути описана у вигляді коливальних ланок з розосередженими параметрами [3], то у випадку співпадіння або кратності частот опромінюючого електромагнітного сигналу та власних коливань елементарних частинок, що складають кристалічну решітку радіопоглинаючого матеріалу, виникає резонансний ефект перевипромінювання електромагнітної енергії.

Таким чином, радіопоглинаючий матеріал переходить в збуджений стан і втрачає свої поглинаючі властивості. Також, було визначено, що управління станом прикордонного шару радіопоглинаючого матеріалу можливе за допомогою варіювання фази зондуючого сигналу (тобто підстроюванням несучої частоти).

Виходячи з цього, можна зробити висновок, що резонансний ефрект може досягатися не тільки за рахунок співпадіння частоти зондуючого сигналу і власних коливань кристалічної структури фюзеляжу, вкритого радіопоглинаючим матеріалом, але й при виконанні умов фазового збігу. Ефект фразового збігу і спостерігався під час проведення експерименту при зміні кута опромінювання зразка.

Резонансні явища на близьких до розрахованих частотах при повторних експериментах підтверджують правильність одержаних результатів [2]. Резонансна частота (або частота биття) буде становити для фрторопласту та для кордієриту.

Характер залежностей амплітуди віддзеркаленого сигналу від кута опромінювання, який був отриманий в результаті вимірювань свідчить про появу періодичних резонансних, так би мовити, "вікон прозорості"відповідно до кількості напівхвиль, розташованих в лінійному розмірі цілі. Зазначений ефект дозволяе стверджувати, що при можливості знаходження оптимальних кутів опромінювання, прийому, значень частоти, а також при відповідних удосконаленнях РТС щодо методу їх визначення, існують шляхи виявлення зі штучно зменшеною площею віддзеркалення.

Головним недоліком отриманого резонансного сигналу є його нестабільність, що призводить до інформаційної невизначеності про параметри руху. Крім того, сигнал биття $є$ некорельованим у часі і 
не дає можливості визначення його параметрів, які необхідні для подальшого розрахунку дальності та швидкості руху.

Виходячи з цього, отриманий резонансний сигнал не дозволяє здійснювати стійке супроводження літака. Аналіз існуючих способів вторинної обробки радіолокаційної інформації свідчить про неможливість їх застосування при супроводженні в умовах виникнення інформаційної невизначеності про параметри руху. Тому виникає необхідність розробки інших методів і алгоритмів для вирішення завдання надійного супроводження.

Проведені дослідження [2] показують, що нестабільності отриманого збудженого резонансного сигналу можливо позбутись завдяки комплексному використанню декількох джерел для оцінки параметрів руху цілі від активних (РТС) та пасивних (оптичні засоби, тепловізори) засобів локації при поєднанні отриманої інформації у вирішальному правилі. Це правило можна покласти в основу пасивно-активного методу траєкторної підтримки супроводження траси в системах супроводження . Метод полягає в узагальненні інформації про параметри руху i, яка надійшла від активних та пасивних засобі виявлення. Підвищення точності грунтуеться на отриманні оціночних значень виміряних координат положення в кутомістній і азимутальній площинах та обчисленні і оцінці дальності до цілі. Оцінені значенні параметрів руху в подальшому можуть використовуватись в навігації.

В якості пасивних засобів отримання інформації про параметри руху повітряної цілі пропонується використовувати радіо-оптичні антенні решітки в оптичному діапазоні електромагнітних хвиль [4]. В інфрачервоному діапазоні електромагнітних хвиль існує можливість первинної обробки інформації про обєкт за допомогою застосування принципів, покладених в основу функціонування тепловізорів [5]. Дальність дії цих засобів досягає 70-80 км, яка співвідноситься з дальністю дії активних РТС.

З аналізу певних залежностей можна визначити, що при відстані між динамічними об'єктами в діапазоні і при імовірності ухвалення рішення правильного ототожнення вимірів, імовірність помилкового рішення не буде перевищувати значення 0,1 [2]. Таким чином, реалізація даного методу ототожнення вимірів РЛС і пасивних засобів виявлення дозволить істотно зменшити кількість помилкових траєкторій на етапах зав'язки і їхньому супроводі.

Для вирішення задачі визначення дальності з малою ЕПВ на різних частотах зондуючого та збудженого сигналу перевипромінювання (сигналу биття) можна використати спосіб, в основу якого покладено вимірювання затримки часу між випромінюванням збуджуючого сигналу і отриманням сигналу випромінювання композитного матеріалу фюзеляжу в збудженому стані на частоті биTTЯ. 
Запропонований спосіб виміру дальності може бути використаний при неможливості застосування когерентно-імпульсного способу, оскільки не відбувається віддзеркалення зондуючого радіоімпульсу на фріксованій частоті. Для реалізації цього способу збуджуючий сигнал (рис. 4а) повинен містити спектральні складові, які кратні до резонансної частоти вільних коливань композитного матеріалу фюзеляжу .

Енергетичні коливання як елементарних частинок, так і кристалічної решітки в цілому, - складний процес, який умовно можна зобразити у вигляді гармонічної фрункції з амплітудою, що промодульована гармонічною фрункцією з енергетичним спектром [3]. Відомо, що коливання елементарних частинок відбувається на частоті [3], тобто вплив збуджуючого сигналу неможливий, оскільки існуючі генератори не здатні генерувати електромагнітний сигнал такої високої частоти.

Однак, відповідно до результатів проведеного експерименту [2], спектр зондуючого сигналу має спектральні складові в діапазоні власних коливань елементарних частинок i, за умови фразового збігу, здатний збуджувати радіопоглинаючий матеріал. Відповідно до класичного методу виміру дальності [6], необхідно визначити час появи від цілі збудженого (резонансного) сигналу на частоти биття ( ). Це завдання можливо вирішити за допомогою використання панорамного приймача з миттевою зміною смуги перепускання.

Спектр прийнятого сигналу биття на виході панорамного приймача буде наближатись до вигляду аркового синусу.

\section{Висновки}

Результати досліджень показують, що наведений методи визначення даних в принципі може бути використаний для удосконалення систем автоматичного виявлення і супроводження .

Продовження проведення досліджень можливе в напрямку оцінки використання отриманих відомостей про параметри руху , тобто визначити ступінь достатності і точності визначення координат для реалізації стійкого автоматичного виявлення і супроводження повітряних літальних апаратів зі штучно зменшеною площею віддзеркалення.

Технічна реалізація запропонованих рішень нададуть можливість удосконалення автоматичних систем супроводження .

\section{Список використанної літератури}

1. Солонніков В.Г., Пархомей І.Р., Рукосуев В.В. Аналіз можливостей щодо виявлення літаків зі штучно зниженою площею віддзеркалення. - К.: Зб. наук. пр. ННДЦ . - № 5(25), 2004 р. C.147-153 
2. Пархомей I.P. Літак як об’єкт радіолокації // Адаптивные системы управления. - К.: Сб. НТУ “КПИ". - № 3(24), 2000 р. C.26-32

3. Карапетьянц М.Х., Дракин С.И. Строение вещества. - М.: Высшая школа, 1978 г. - 304 с.

4. Воскресенский Д.И., Гринев Д.Ю. Радио-оптические антенные решетки. - М.: Радио и связь, 1986 г. - 236 с.

5. Несветей Э.А. Специальные вопросы радиоэлектроники. - К.: Изд. КНУ, 1990 г. -416 с.

6. Локационная системотехника/Под общ. ред. В.Б. Алмазова. Харьков, изд. ХВУ ПВО, 1993. - 618 с.

Отримано 20.10.2015 p. 